\title{
Extractable Phosphorus and Rice Yield in an Ultisol of the Humid Forest Zone in West Africa
}

\author{
K. L. Sahrawat, M. P. Jones, and S. Diatta \\ West Africa Rice Development Association (WARDA), 01 B.P. 2551 Bouake, \\ Ivory Coast, West Africa
}

\begin{abstract}
Little attention has been devoted to calibrating soil tests for phosphorus (P) in the field for upland rice in West Africa. The information is needed to improve fertilizer $P$ recommendations. A field experiment was conducted in the rainy season of 1994 to establish the relationship between extractable $P$ by Bray 1 and grain yield of four upland rice cultivars grown on an Ultisol in the forest zone of Ivory Coast. The critical limit of Bray $1 \mathrm{P}$ in the soil at $90 \%$ relative rice grain yield varied from 12.5 to $15.0 \mathrm{mg} \mathrm{P} / \mathrm{kg}$ of soil for the four cultivars tested. The $\mathrm{P}$ critical limit in the soil tended to be lower for the cultivars of rice earlier found to be efficient at converting applied $\mathrm{P}$ into grain yield.
\end{abstract}

\section{INTRODUCTION}

The upland ecosystem in West Africa is very important to rice production (Enyi, 1984). A large area of upland rice is in the humid forest zone of the region. Phosphorus deficiency has been identified as one of the major limiting factors for crop production in highly weathered Oxisols and Ultisols in the tropics (Sanchez and Salinas, 1984; Warren, 1992). 
Despite a great deal of research on soil $\mathrm{P}$, much still remains to be leamed about the management of acid soils in relation to $P$ requirement of upland rice in the humid tropics of West Africa. We initiated a study for developing a $P$ management strategy for upland rice grown on acid soils in the humid forest zone of West Africa. Phosphorus deficiency is a major constraint to rice production on these soils (Sahrawat et al., 1995). Initially, we measured the $\mathrm{P}$ responsiveness and $P$ requirements of promising, acidity-tolerant upland rice cultivars by growing them on a low P status Ultisol in the humid forest zone of Ivory Coast. The cultivars tested responded well to applied $\mathrm{P}$ and there was little further response in grain yield at higher rates than $60 \mathrm{~kg} P / \mathrm{ha}$. The results suggested that $P$ fertilization of soil acidity-tolerant upland rice cultivars can significantly improve the productivity of Ultisols (Sahrawat et al., 1995).

However, to improve fertilizer P recommendations, information is also needed on the calibration of soil tests for $\mathrm{P}$ in the field for upland rice. The objective of the work reported in this paper, therefore, was to calibrate soil $P$ test by establishing a relationship between extractable $P$ and yield of upland rice.

\section{MATERIALS AND METHODS}

A field study was conducted in 1994 at the Institut des savanes (IDESSA) station near Man $\left(7.2^{\circ} \mathrm{N}, 7.4^{\circ} \mathrm{W}\right.$; altitude $\left.500 \mathrm{~m}\right)$ in Ivory Coast. This site is located in the humid forest zone and has previously been used to measure $\mathrm{P}$ response of upland rice cultivars. The area receives on average a total annual rainfall of about $1700 \mathrm{~mm}$ (Sahrawat et al., 1995).

The soil at the experimental site was an Ultisol [pH, water 4.9; $\mathrm{pH}, \mathrm{KCl} 4.0$; organic carbon (C) $0.135 \mathrm{~g} / \mathrm{kg}$; total P $155 \mathrm{mg} / \mathrm{kg}$ ]. Soil samples were collected from surface $(0-20 \mathrm{~cm})$ layer before initiating the experiment, air dried and crushed to pass a 2-mm screen before analysis. Soil $\mathrm{pH}$ was measured by a glass electrode

TABLE 1. Range in grain yields of the four upland rice cultivars and Bray-1 P content in the Ultisol, Man, Ivory Coast, 1994.

\begin{tabular}{lccccc}
\hline & \multicolumn{4}{c}{ Rice cultivars } & \\
\cline { 2 - 5 } & WAB & WAB & WAB & \\
Parameter & $56-125$ & $56-104$ & $56-50$ & IDSA6 & All cultivars \\
\hline $\begin{array}{l}\text { Grain yield } \\
\text { (t/ha) }\end{array}$ & $0.86-2.42$ & $0.79-2.18$ & $0.64-2.05$ & $0.74-1.92$ & $0.64-2.42$ \\
$\begin{array}{l}\text { Bray 1 P } \\
\text { (mg/kg) }\end{array}$ & $6-20$ & $5-23$ & $6-26$ & $6-19$ & $5-26$ \\
\hline
\end{tabular}


using a soil to water or salt $(1 \mathrm{M} \mathrm{KCl})$ solution ratio of 1:2.5. Organic $C$ was deternined as described by Walkley and Black (1934). Total P content in the soil was determined by digestion with perchloric acid, and the extractable $\mathrm{P}$ was extracted with $\mathrm{NH}_{4} \mathrm{~F}-\mathrm{HCl}$, generally referred to as Bray 1 solution, using a soil to extractant ratio of 1:7 (Olsen and Sommers, 1982). Phosphorus in the extracts was detennined colorimetrically using the phosphomolybdate blue color method.

The experiment was conducted in the rainy season (June-October), to establish relationship between extractable $P$ and rice grain yield. The rainfall received during the growing season was $684 \mathrm{~mm}$. The experiment had a 2-factorial randomized complete block design with four replications. Factor 1 was $P$ application in 1993 at five rates $(0,45,90,135$, and $180 \mathrm{~kg} \mathrm{P} / \mathrm{ha})$ as triple superphosphate (TSP). Factor 2 was variety and the four upland rice cultivars used were WAB 56-125, WAB 56-104, WAB 56-50, and IDSA 6. The experiment had 80 plots (20 plots for each cultivar). The plots at the site had received fertilizer $\mathrm{P}$ as TSP ranging from 0 to $180 \mathrm{~kg} P /$ ha during the 1993 season. They had a wide range in extractable $P$ (Table 1) as determined on soil samples taken after harvest of the 1993 season crops and before planting of the experiment in 1994. The cultivars of upland rice were sown in rows at a spacing of $25 \mathrm{~cm}$. Each plot (5x3 m) received fertilizer nitrogen $(N)$ (total $100 \mathrm{~kg} \mathrm{~N} / \mathrm{ha}$ ) as urea in three splits at planting, tillering, and flowering. Plots were hand weeded at 3 and 6 weeks after seeding.

The crops were harvested at maturity and grain and straw weights were recorded at $14 \%$ moisture. The grain and straw samples were analyzed for $P$ by digesting the samples with a 2:1 mixture of nitric and perchloric acids. The $P$ in the plant digests was analyzed by the vanadomolybdate yellow color method.

The Cate and Nelson (1971) method of graphic presentation was used to establish relationship between extractable $P$ and relative rice grain yield of the cultivars and to arrive at a critical limit of extractable $P$ in the soil for each of the four cultivar. Relative grain yield was calculated relative to maximum yield. This method has been found to be useful and has practical advantages in addition to showing whether good correlation existed. It divided the data into responsive and non- responsive populations (Dahnke and Olson, 1990).

\section{RESULTS AND DISCUSSION}

Range in grain yields of the four upland rice cultivars and Bray $1 \mathrm{P}$ content in the Ultisol are shown in Table 1. The cultivars had a wide range grain yield and the highest grain yield for each cultivar, with the exception of IDSA 6, exceeded 2 tha. We had previously reported that WAB cultivars were relatively efficient and gave a better response than IDSA 6 to applied P (Sahrawat et al., 1995). These results supported earlier results on $P$ efficiency of the cultivars.

The relationships between relative rice grain yield and extractable $P$ by Bray 1 $P$ for the four cultivars are shown in Figure 1. The data revealed that there were 
WAB $56-125$

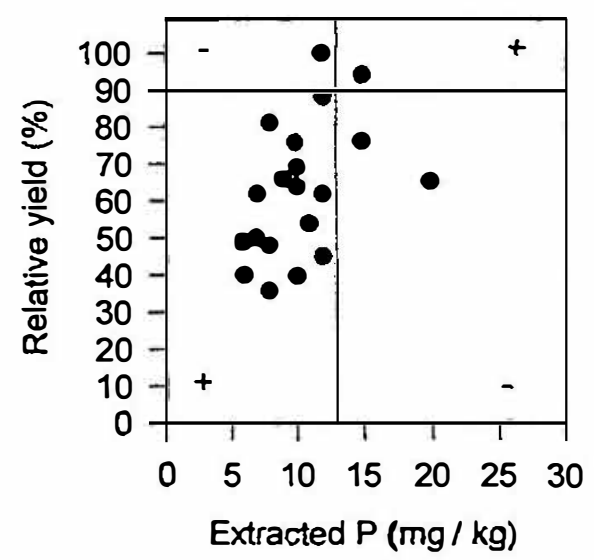

WAB 56 - 50

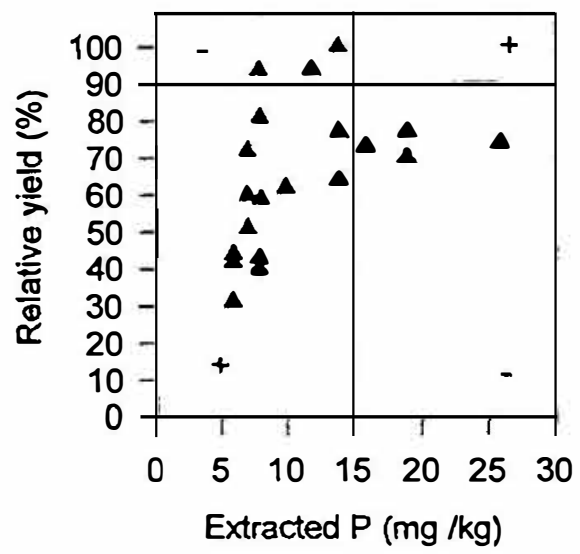

WAB $56-104$

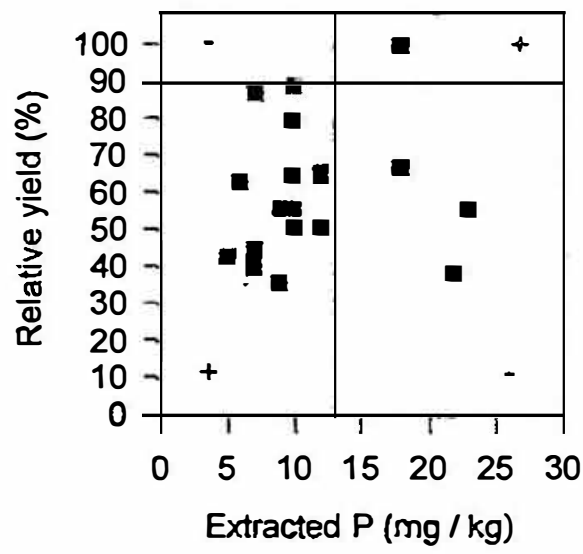

IDSA 6

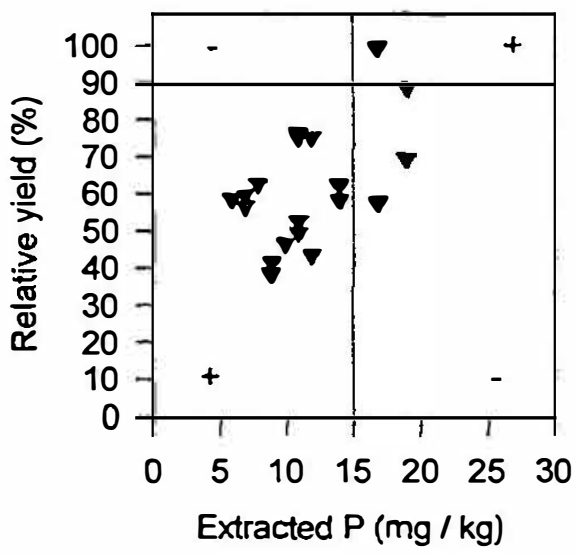

FIGURE 1. Relationship between extracted $\mathrm{P}$ and relative rice grain yield for the four upland rice cultivars.

differences in extractable $P$, at which $90 \%$ relative yield was achieved by the four cultivars tested. The level of Bray 1 in the soil at $90 \%$ relative grain yield was found to be 12.5 for WAB 56-125, 13.5 for WAB 56-104, and $15.0 \mathrm{mg} \mathrm{P} / \mathrm{kg}$ of soil each for WAB 56-50 and IDSA 6 (Figure 1). The data also showed that for two out of the three WAB cultivars which were found to be efficient in utilizing $P$ for grain production (Sahrawat et al., 1995) achieved the $90 \%$ relative grain yield at lower extractable P levels in the soil than IDSA 6. When the data for all four cultivars were pooled to plot the relationship between Bray $1 \mathrm{P}$ and relative rice grain yield, a critical limit of $16.0 \mathrm{mg} \mathrm{P} / \mathrm{kg}$ soil was obtained at $90 \%$ relative yield (Figure 2). 


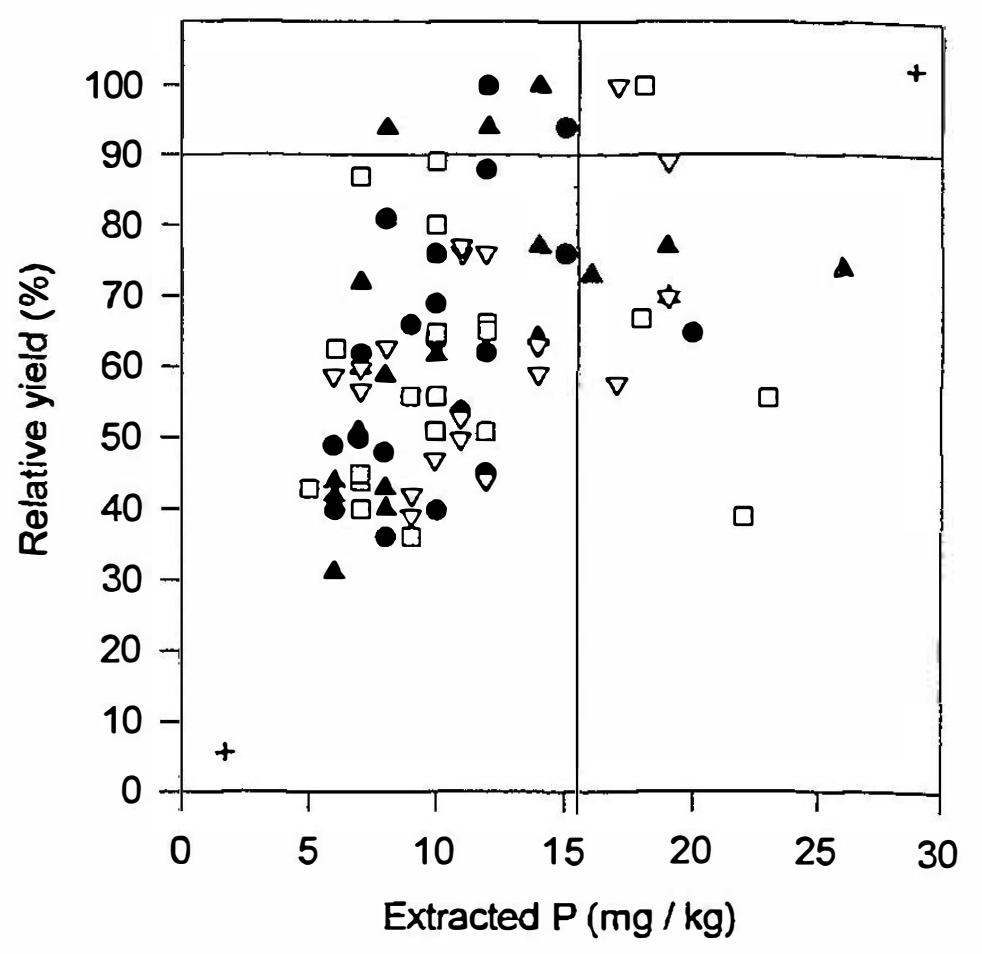

- WAB $56-125$

- WAB $56-104$

- WAB $56-50$

$\nabla \quad$ IDSA 6

FIGURE 2. Relationship between extracted $\mathrm{P}$ and relative rice grain yield with pooled data for the four upland rice cultivars.

The results of this study establish that the critical limit of Bray $1 \mathrm{P}$, commonly employed for assessing available $P$ status of acidic soils, vary from 12.5 to 15.0 $\mathrm{mg} P / \mathrm{kg}$ of soil for the four cultivars tested. A relatively lower critical limit in extractable $P$ in soil for the $P$ efficient cultivars can be interpreted as supportive of our earlier results on agronomic and physiological $P$ efficiencies of these cultivars (Sabrawat et al., 1995). The methodology based on growing cultivars on a soil with a range in extractable $P$, created by different levels of $P$ fertilization, can also be gainfully employed for testing cultivars for P efficiency.

\section{REFERENCES}

Cate, Jr., R.B. and L.A. Nelson. 1971. A simple statistical procedure for partitioning soil test correlation data into classes. Soil Sci. Soc. Am. Proc. 35:658-660. 
Dahnke, W.C. and R.A. Olson. 1990. Soil test, calibration, and recommendation, pp. 45 . 71. In: R.L. Westerman, J.V. Baird, N.W. Christensen, P.E. Fixen, and D.A. Whitney (eds.), Soil Testing and Plant Analysis. 3rd ed. Series 3. Soil Science Society of America, Madison, WI.

Enyi, B.A.C. 1984. Upland rice production in West Africa. Oryza 20:5-14.

Olsen, S.R. and L.E. Sommers. 1982. Phosphorus, pp. 403-430. In: A.L. Page, R.H. Miller, and D.R. Keeney (eds.), Methods of Soil Analysis. Part 2, Agronomy 9. American Society of Agronomy, Madison, WI.

Sahrawat, K.L., M.P. Jones, and S. Diatta. 1995. Response of upland rice to phosphorus in an Ultisol in the humid forest zone of West Africa. Fert. Res. 41:11-17.

Sanchez, P.A. and J.G. Salinas. 1981. Low input technology for managing Oxisols and Ultisols in tropical America. Adv. Agron. 34:280-406.

Walkley, A. and I.A. Black. 1934. An examination of the Degtjareffmethod for determining soil organic matter and proposed modification of the chromic acid method. Soil Sci. 29:29-38.

Warren, G.P. 1992. Fertilizer Phosphorus: Sorption and Residual Value in Tropical African Soils. NRI Bull. 37, Natural Resources Institute, Chatham, UK. 